\title{
Tall fescue sward structure affects the grazing process of sheep
}

Leonardo Silvestri Szymczak ${ }^{1 凶}$, Anibal de Moraes ${ }^{1}$, Reuben Mark Sulc ${ }^{2}{ }^{2}$, Alda Lucia Gomes Monteiro ${ }^{3}$, Claudete R. Lang ${ }^{1}$, Renata Francieli Moraes ${ }^{1} 1$, Delma Fabiola Ferreira da Silva ${ }^{1}$, Carolina Bremm ${ }^{4}$ \& Paulo César de Faccio Carvalho ${ }^{5}$

The study of factors influencing animal intake can provide a better understanding of the dynamics of the pasture ecosystem and serve as a basis for managing livestock in a more efficient way. We measured different sward surface heights of tall fescue in the process of short-term intake rate of sheep. There was a significant effect of sward surface height on herbage mass $(P<0.001)$, leaf lamina mass $(P<0.001)$, other species mass $(P=0.02)$, bite mass $(P=0.01)$ and short-term intake rate $(P=0.03)$ of sheep. There was a quadratic fit between time per bite and bite mass $(P=0.006)$. Multivariate analysis showed that the short-term intake rate and bite mass were positively correlated $(r=0.97)$, bite rate and total jaw movement rate were positively correlated but both were negatively correlated with time per bite. The sward surface height of tall fescue corresponding to the maximum short-term herbage intake rate was $22.3 \mathrm{~cm}$. The underlying processes were driven by the bite mass, which was influenced by the leaf lamina bulk density and its consequences upon time per bite. This sward surface height can be adopted as a pre-grazing target for rotational stocking systems to optimize sheep nutrition on pastures.

In recent years alternative management of agricultural systems have been sought that support the principles of eco-efficiency ${ }^{1-3}$. Carvalho et al. ${ }^{4}$ and Laca et al. ${ }^{5}$ presented a perspective on precision livestock management, which is based on productive efficiency with environmental responsibility. A way to achieve these goals is through the understanding and mimicry of natural ecological processes ${ }^{6}$.

For millions of years herbivores and forage plants have been in a co-evolutionary pathway. Foraging strategies were developed to optimize herbage intake and meet the requirements for quantity and quality of feed that allow performance of other daily activities. In contrast, forage plants have developed morphological structures that restrict grazing in order to favor the development, growth and preservation of the species ${ }^{-10}$.

The intake rate represents the consumption of forage per unit of time and is considered a fundamental component of the ingestive behaviour of grazing animals, being the product of bite mass and bite rate. In this context, the bite can be considered as the first scale of the grazing process ${ }^{11-14}$ and therefore, is under direct influence of the sward structure ${ }^{8}$.

Structural characteristics of the forage sward can stimulate, inhibit or limit the ingestive behaviour of animals ${ }^{15-17}$. These structural variables include leaf length and shape, cuticle thickness, stem physical properties, tiller density, proportion of senescent material, proportion and quantity of leaf blades, all of which are dependent on the species, growth habit, height, morphogenic characteristics, life cycle and longevity of the forage plant ${ }^{17-24}$. Thus, in the context of competition strategy at the plant-animal interface, the animals adapt to changes found in the pasture at the time of grazing, which promote behavioural changes, such as altering the pattern of displacement, food selection, the ratio of mass acquired and rate of harvest by animals, and mandibular and non-mandibular movements ${ }^{25-28}$.

The ingestive behaviour of animals has great relevance because it determines the daily nutrient intake and animal performance, as well as the location and intensity of the animal's impact on the vegetation as well as the

\footnotetext{
${ }^{1}$ Department of Crop Production and Protection, Federal University of Paraná, Rua dos Funcionários 1540, Curitiba, Paraná 80035-050, Brazil. 2Department of Horticulture and Crop Science, The Ohio State University, 2021 Coffey Road, Columbus, OH 43210-1086, USA. ${ }^{3}$ Departament of Animal Science, Federal University of Paraná, Rua dos Funcionários 1540, Curitiba, Paraná 80035-050, Brazil. "'Department of Agricultural Diagnosis and Research, Secretary of Agriculture, Livestock and Irrigation of Rio Grande Do Sul, Rua Gonçalves Dias 570, Porto Alegre, Rio Grande do Sul 90130060, Brazil. ${ }^{5}$ Department of Forage Plants and Agrometeorology, Federal University of Rio Grande Do Sul, Av. Bento Gonçalves 7712, Porto Alegre, Rio Grande do Sul 91540-000, Brazil. ${ }^{\varpi}$ email: sisz.leonardo@gmail.com
} 


\begin{tabular}{|c|c|c|c|c|c|c|c|}
\hline & \multicolumn{5}{|c|}{ Sward surface height $(\mathrm{cm})$} & \multirow[b]{2}{*}{ SEM } & \multirow[b]{2}{*}{$P$ value } \\
\hline & 14 & 17 & 20 & 23 & 26 & & \\
\hline SSH pre-* & $14.2^{\mathrm{e}}$ & $17.3^{\mathrm{d}}$ & $19.7^{\mathrm{c}}$ & $22.8^{\mathrm{b}}$ & $25.9^{\mathrm{a}}$ & 0.12 & 0.000 \\
\hline SSH post- & $14.0^{\mathrm{e}}$ & $17.0^{\mathrm{d}}$ & $19.6^{c}$ & $22.7^{\mathrm{b}}$ & $25.9^{\mathrm{a}}$ & 0.12 & 0.000 \\
\hline HM & $1825^{\mathrm{b}}$ & $1956^{\mathrm{b}}$ & $2176^{\mathrm{ab}}$ & $2158^{\mathrm{ab}}$ & $2511^{\mathrm{a}}$ & 59.1 & 0.000 \\
\hline LLM & $1046^{c}$ & $1258^{\mathrm{bc}}$ & $1387^{\mathrm{b}}$ & $1333^{\mathrm{b}}$ & $1659^{\mathrm{a}}$ & 34.6 & 0.000 \\
\hline PSM & 454 & 421 & 442 & 444 & 510 & 17.3 & 0.785 \\
\hline SM & 377 & 278 & 347.69 & 381 & 342 & 16.5 & 0.743 \\
\hline OSM & $17^{\mathrm{b}}$ & $48^{\mathrm{ab}}$ & $37^{\mathrm{ab}}$ & $31^{\mathrm{ab}}$ & $71^{\mathrm{a}}$ & 5.0 & 0.020 \\
\hline
\end{tabular}

Table 1. Actual sward surface heights pre- and post-grazing ( $\mathrm{SSH}, \mathrm{cm})$, total herbage mass $\left(\mathrm{HM}, \mathrm{kg} \mathrm{DM} \mathrm{ha}^{-1}\right)$, leaf lamina mass (LLM, $\mathrm{kg} \mathrm{DM} \mathrm{ha}^{-1}$ ), pseudo-stem + sheath mass (PSM, $\mathrm{kg} \mathrm{DM} \mathrm{ha}^{-1}$ ), senescent mass (SM, $\mathrm{kg}$ $\left.\mathrm{DM} \mathrm{ha}^{-1}\right)$ and other species mass (OSM, $\mathrm{kg} \mathrm{DM} \mathrm{ha}^{-1}$ ) as a function of intended swards surface heights $(\mathrm{cm})$ of Schedonorus arundinaceus [Schreb.] Dumort (tall fescue). SEM standard error of mean. ${ }^{\mathrm{a}-\mathrm{e}}$ Means within a row with different superscripts differ $(P<0.05)$ by Tukey's test. ${ }^{\star}$ There was no significant difference between preand post-grazing SSH for each treatment $(P=0.19$ for $14 \mathrm{~cm}, P=0.29$ for $17 \mathrm{~cm}, P=0.15$ for $20 \mathrm{~cm}, P=0.10$ for $23 \mathrm{~cm}$ and $P=0.78$ for $26 \mathrm{~cm}$ ).

soil. Thus, a better understanding of ingestive behaviour can lead to a better understanding of the dynamics of the pasture ecosystem, providing the basis for more efficient management of animals and forage plants ${ }^{14,19,29}$.

In this experiment we tested the hypothesis that short-term intake rate (STIR) in sheep is maximized with intermediate tall fescue sward structures, expressed in sward surface height (SSH), and that both lower and higher SSH results in a decrease in bite mass. The specific objective of this study was to evaluate different SSH of a temperate perennial forage (S. arundinaceus [Schreb.] Dumort cv. Aurora), in the process of STIR of sheep, from a perspective of optimization of pasture management.

\section{Results}

The actual pre- and post-grazing SSH increased linearly with expected SSH (treatments). There was no significant difference between pre- and post-grazing SSH for each treatment $(P=0.19$ for $14 \mathrm{~cm}, P=0.29$ for $17 \mathrm{~cm}$, $P=0.15$ for $20 \mathrm{~cm}, P=0.10$ for $23 \mathrm{~cm}$ and $P=0.78$ for $26 \mathrm{~cm}$ ) with each grazing test period, so the average values between pre- and post-grazing were used for forage variables. The actual pre-grazing SSH were very similar to the intended SSH (Table 1).

There was a significant effect of SSH treatment on HM $(P<0.001)$, LLM $(P<0.001)$ and OSM $(P=0.02)$ (Table 1). There was a linear relationship between the SSH and the LLM and HM. There was no significant effect of the SSH on the PSM $(P=0.78)$ and SM $(P=0.74)$, so the increase of HM is related to the increase of LLM.

A significant SSH $\times$ stratum interaction was found for leaf lamina bulk density $(P<0.001)$, herbage total bulk density $(P=0.05)$ and number of leaf lamina $(P<0.001)$. For the pseudo-stem + sheath bulk density, there was a significant effect only between strata $(P<0.001)$. The highest leaf lamina bulk density occurred in stratum $3-6 \mathrm{~cm}$ for SSH of 14, 6-9 cm for SSH of 17, 20 and $23 \mathrm{~cm}$ and 9-18 cm for SSH of 26 . As there was an increase in the SSH pre-grazing, there was also a linear increase in the leaf lamina bulk density (Fig. 1). The pseudo-stem + sheath bulk density was higher in the first stratum, decreasing in the upper strata (Fig. 2). The highest herbage total bulk density occurred in the stratum $0-6 \mathrm{~cm}$ for 14 and $20 \mathrm{SSH}, 0-9 \mathrm{~cm}$ for $17 \mathrm{SSH}, 0-3$ for $23 \mathrm{SSH}$ and $0-18 \mathrm{~cm}$ in the $26 \mathrm{SSH}$ (Fig. 3). With the increase of the SSH pre-grazing, there was also an increase in herbage total bulk density in the upper strata (Fig. 3). The highest number of leaf lamina occurred in the stratum 3-9 $\mathrm{cm}$ for $14 \mathrm{SSH}, 6-12 \mathrm{~cm}$ for 17 and $20 \mathrm{SSH}, 6-18 \mathrm{~cm}$ for $23 \mathrm{SSH}$ and $9-18 \mathrm{~cm}$ for the $26 \mathrm{SSH}$, consequently having a reduction of leaf number in the upper and lower strata (Fig. 4). During the grazing tests, the presence of other species was verified, with a larger mass of these at SSH of 26 and a smaller at SSH of 14 (Table 1). The proportional mass of other species in all treatments was less than $2.85 \%$ (Table 1). The species found were Trifolium repens L. (seedling stage), Vicia sativa L. (seedling stage), Plantago tomentosa Lam. (vegetative stage), Oxalis corniculata L. (vegetative stage), Artemisia verlotorum Lamotte (vegetative stage) e Cynara cardunculus L. (vegetative stage).

No effect was observed on the BR $(P=0.31)$, TJMR $(P=0.31)$ and TB $(P=0.24)$ as a function of SSH (Fig. 5a, $\mathrm{b}$ and $\mathrm{c}$ respectively). There was a significant effect of SSH of tall fescue on the BM $(P=0.01$, Fig. $5 \mathrm{~d})$ and STIR $(P=0.03$, Fig. 6a). There was a quadratic fit between STIR and SSH, with STIR increasing up to SSH of $22.3 \mathrm{~cm}$ $\left(y=5.61 \mathrm{~g} \mathrm{DM} \mathrm{min}^{-1}\right.$; Fig. 6a) and then decreasing at greater SSH. The model that was best suited for BM as a function of SSH was also quadratic, with increasing BM up to $22.8 \mathrm{~cm}\left(\mathrm{y}=91.52 \mathrm{mg} \mathrm{DM} \mathrm{bite}{ }^{-1}\right.$; Fig. $\left.5 \mathrm{~d}\right)$. A high correlation of $0.97(P<0.001)$ was also observed between STIR and BM variables (Fig. 6b). There was a quadratic fit between TB and $\mathrm{MB}(P=0.006)$, with TB increasing up to BM of $135 \mathrm{mg} \mathrm{DM}$ bite $^{-1}$ and then decreasing at greater BM (Fig. 6c).

Multivariate analysis (Fig. 7) showed that the STIR and BM were positively correlated ( $\mathrm{r}=0.97)$. Bite Rate and TJMR were also positively correlated; however, both were negatively correlated with TB. The individual observations suggest that higher mean values for STIR and BM were obtained at SSH of $20 \mathrm{~cm}$, while higher mean values for TB were obtained at SSH of $26 \mathrm{~cm}$ (Fig. 7). 


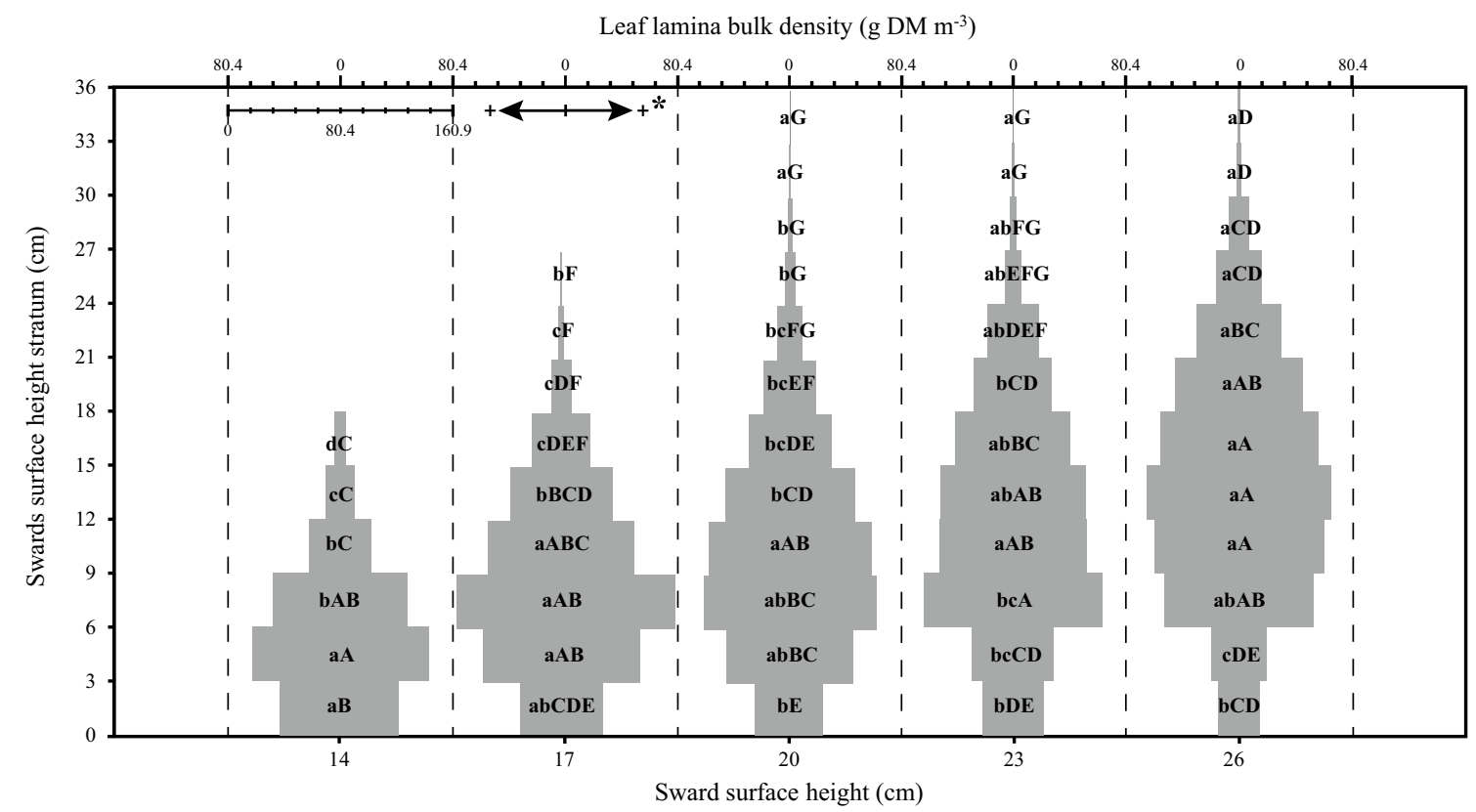

Figure 1. Leaf lamina bulk density by sward strata as a function of sward surface height (SSH) of Schedonorus arundinaceus [Schreb.] Dumort (tall fescue). ${ }^{\star}$ Total values of leaf lamina bulk density at each SSH correspond to the sum of the left and right sides. (a)-(d) The average values within a row with different lowercase letters differ $(P<0.05)$ by Tukey's test. $(\mathbf{A})-(\mathbf{G})$ The average values within a column with different uppercase letter differ $(P<0.05)$ by Tukey's test. $P$ significance level: SSH $P<0.001$; Strata $P<0.001$; SSH $\times$ Strata $P<0.001$.

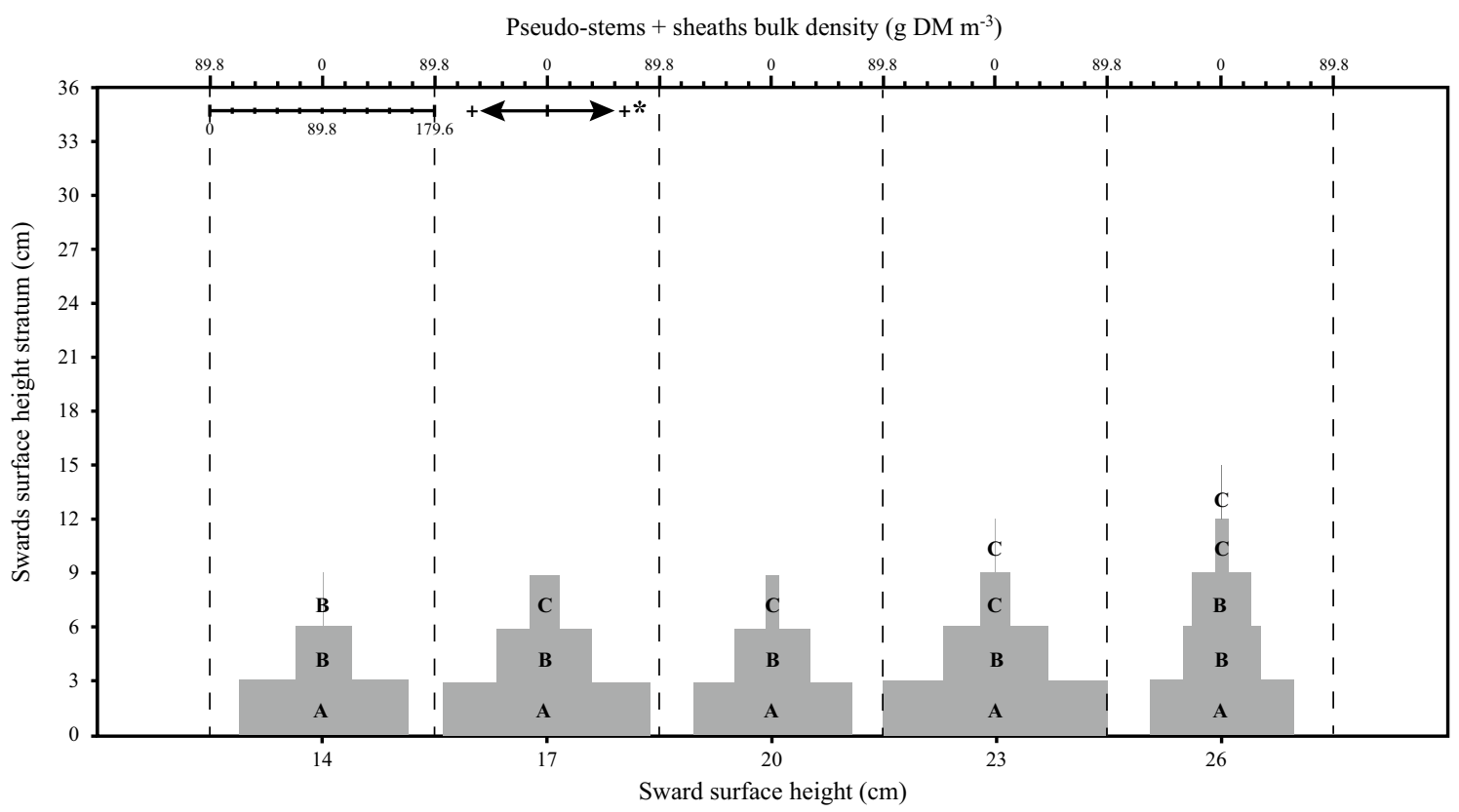

Figure 2. Pseudo-stem + sheath bulk density by sward strata as a function of sward surface height (SSH) of Schedonorus arundinaceus [Schreb.] Dumort (tall fescue). ${ }^{\star}$ Total values of pseudo-stem + sheath bulk density at each SSH correspond to the sum of the left and right sides. (A)-(C) The average values within a column with different uppercase letter differ $(P<0.05)$ by Tukey's test. $P$ significance level: SSH $P=0.349$; Strata $P<0.001 ;$ SSH $\times$ Strata $P=0.366$.

\section{Discussion}

The reduction of pre-grazing SSH by the animals during the grazing tests, as measured by the post-grazing SSH, did not exceed 5\% (Table 1). This indicates that intended SSH were available to the animals from the beginning to the end of the grazing test. 
Total herbage bulk density $\left(\mathrm{g} \mathrm{DM} \mathrm{m}^{-3}\right)$

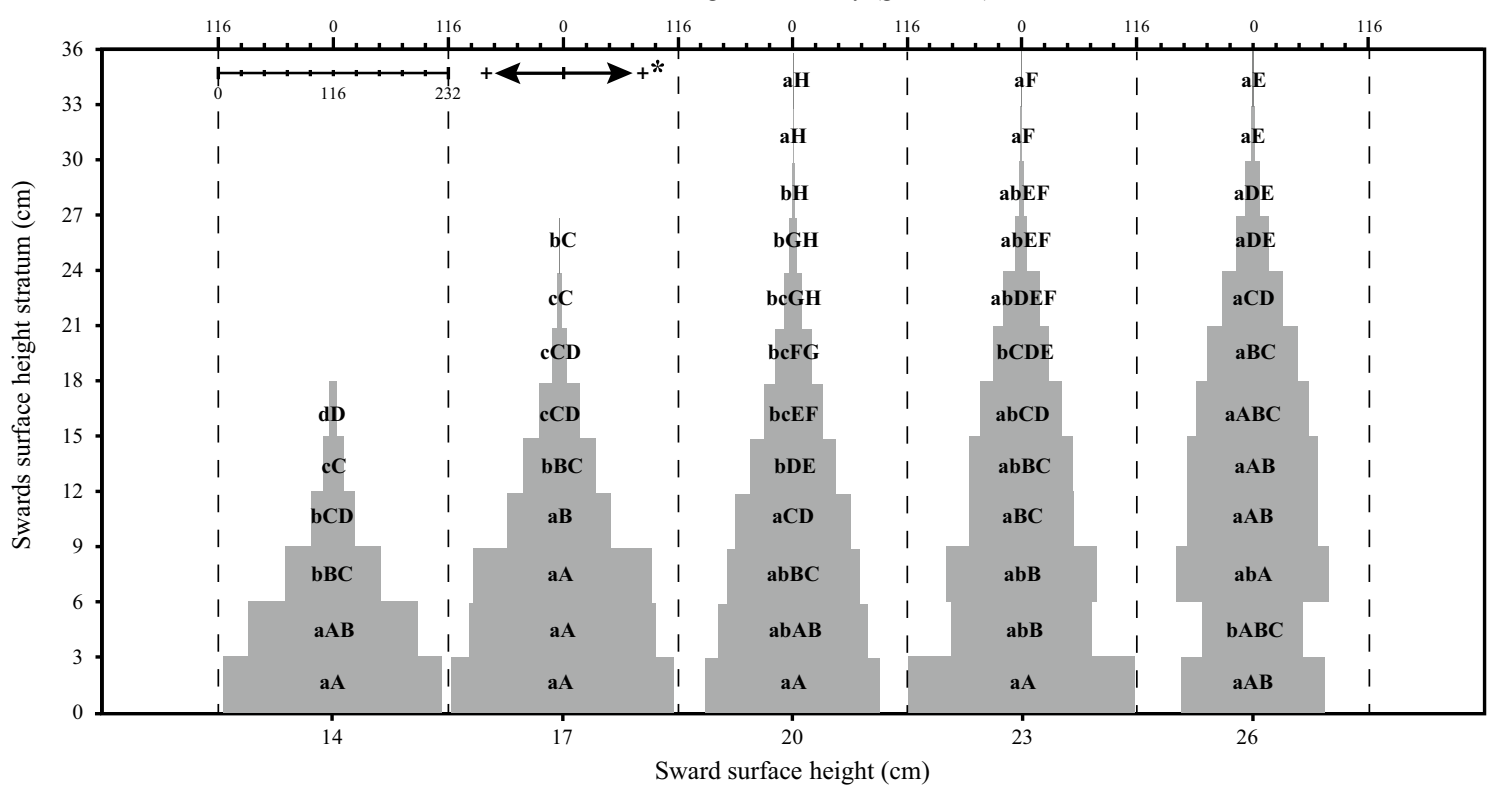

Figure 3. Total herbage bulk density by sward strata as a function of sward surface height (SSH) of Schedonorus arundinaceus [Schreb.] Dumort (tall fescue). ${ }^{\star}$ Total values of total herbage bulk density at each SSH correspond to the sum of the left and right sides. (a)-(d) The average values within a row with different lowercase letters differ $(P<0.05)$ by Tukey's test. $(\mathbf{A})-(\mathbf{H})$ The average values within a column with different uppercase letter differ $(P<0.05)$ by Tukey's test. $P$ significance level: SSH $P<0.001$; Strata $P<0.001$; SSH $\times$ Strata $P=0.05$.

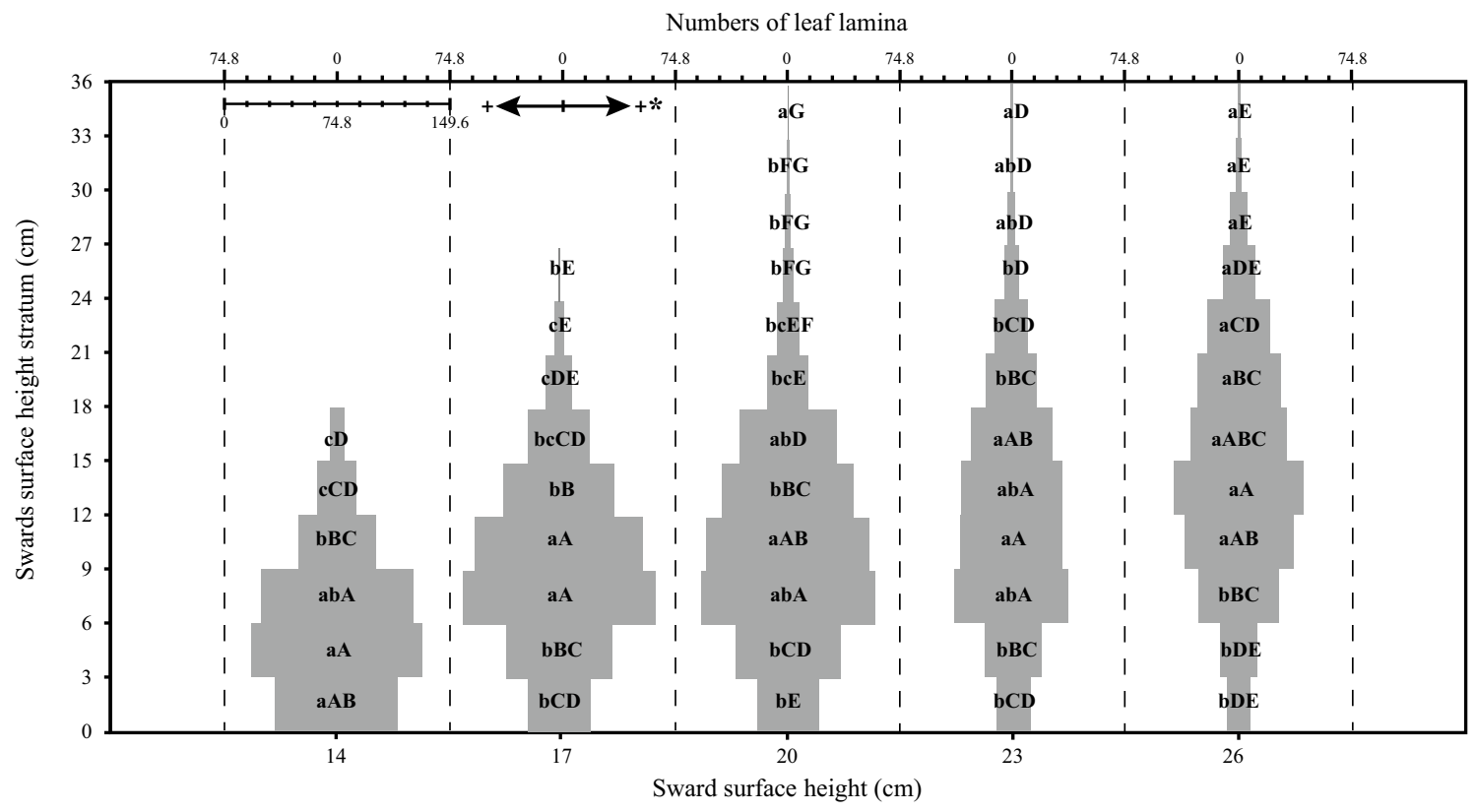

Figure 4. Numbers of leaf lamina by sward strata as a function of sward surface height (SSH) of Schedonorus arundinaceus [Schreb.] Dumort (tall fescue). ${ }^{\star}$ Total values of number of leaf lamina at each SSH correspond to the sum of the left and right sides. (a)-(c) The average values within a row with different lowercase letters differ $(P<0.05)$ by Tukey's test. $(\mathbf{A})-(\mathbf{G})$ The average values within a column with different uppercase letter differ $(P<0.05)$ by Tukey's test. $P$ significance level: SSH $P<0.001$; Strata $P<0.001$; SSH $\times$ Strata $P<0.001$. 

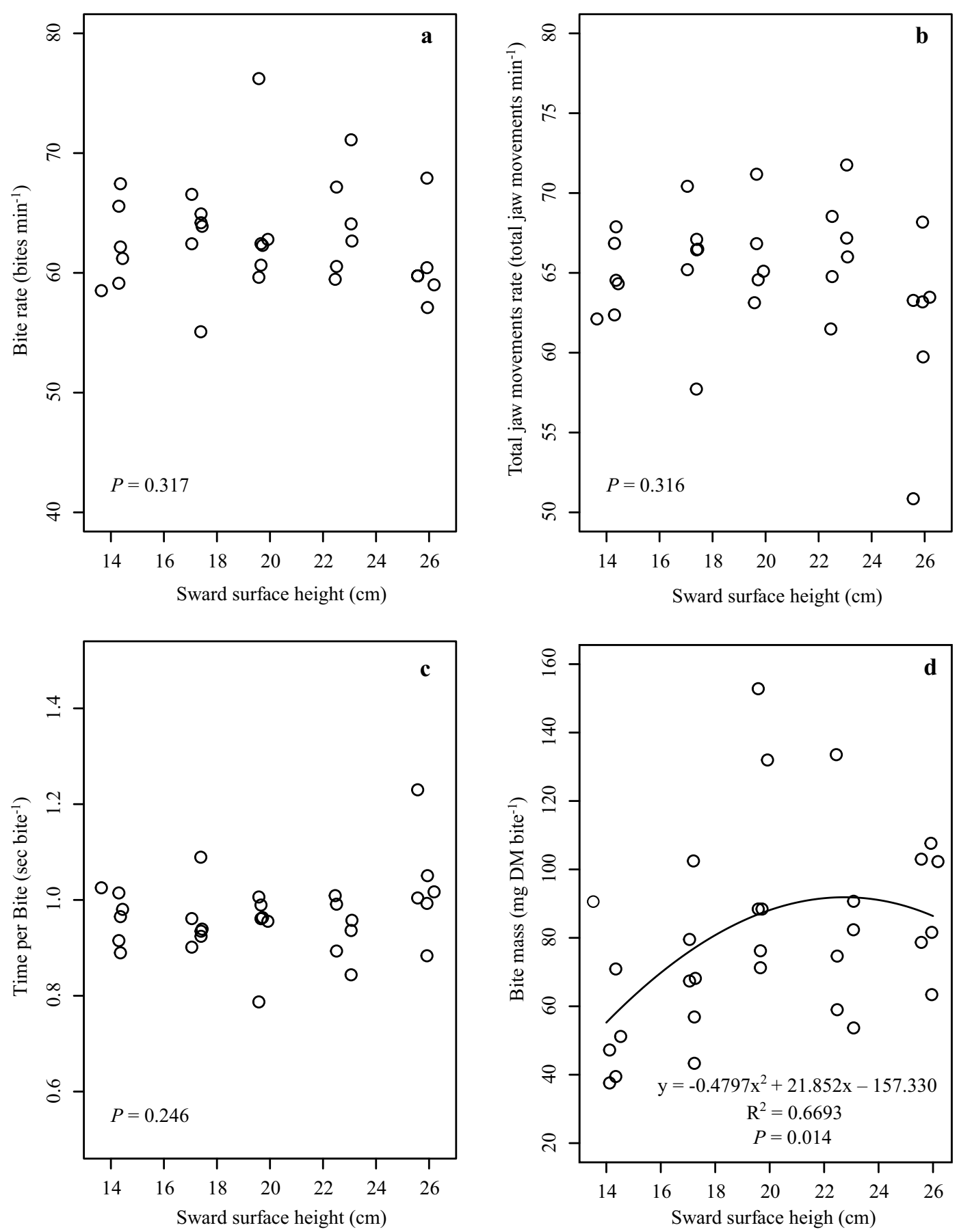

Figure 5. Bite rate (a), total jaw movements rate (b), time per bite (c) and bite mass (d) of sheep as a function of different Schedonorus arundinaceus [Schreb.] Dumort. (tall fescue) sward surface heights (SSH).

The STIR response to SSH was a direct outcome from BM, since BR and TB were not affected by SSH. According to Baumont et al. $^{30}$, sheep have exclusive prehension and mastication jaw movements, so TB would be a sum of a constant prehension time and a mastication time that increases linearly with BM.

Mezzalira et al. ${ }^{22,31}$ also registered similar results of STIR being affected by SSH when evaluating the contrasting sward structures of Cynodon sp. and Avena strigose Schreb. Ungar et al. ${ }^{32}$ and Laca et al..$^{33}$ stated that STIR in homogeneous swards can be explained mainly by BM (Figs. 6B and 7). Thus, interpreting BM behaviour is fundamental for explaining STIR.

The ascendant part of the BM model is mechanistically rationalizable. BM is dependent on the bite volume (defined by bite depth and bite area) and the herbage bulk density of the forage ${ }^{12,34,35}$. At lower SSH the bite volume is commonly restricted by bite depth (e.g. Gregorini et al. ${ }^{36}$ ). As SSH increases from 14 to $22 \mathrm{~cm}, \mathrm{BM}$ also increases mainly as a function of increasing bite depth and leaf lamina bulk density in the grazing horizon. 

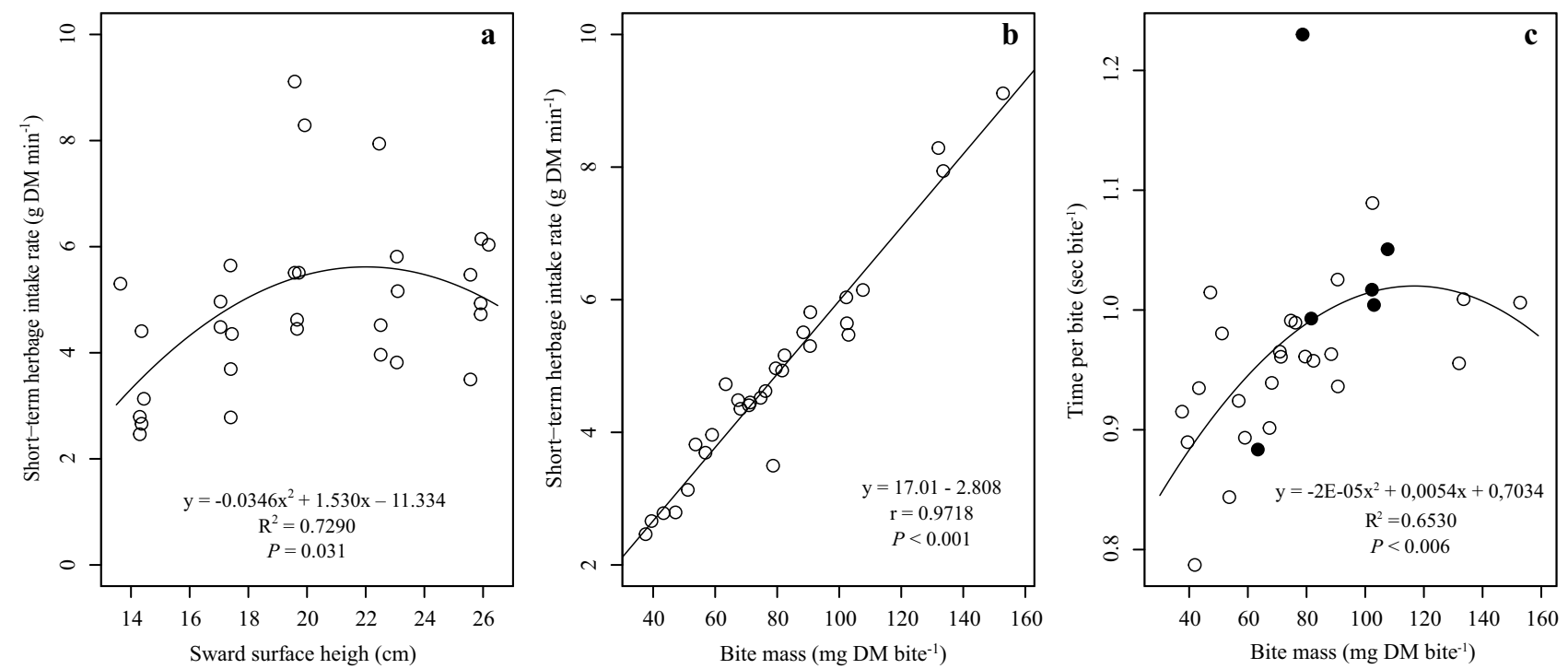

Figure 6. Short-term herbage intake rate as a function of sward surface height (a), relationship between short-term herbage intake rate and bite mass (b) and relationship between time per bite and bite mass (c) black circles represent animals under the effect of a sward surface height of $26 \mathrm{~cm}$ ) of sheep in a Schedonorus arundinaceus [Schreb.] Dumort (tall fescue) pasture.

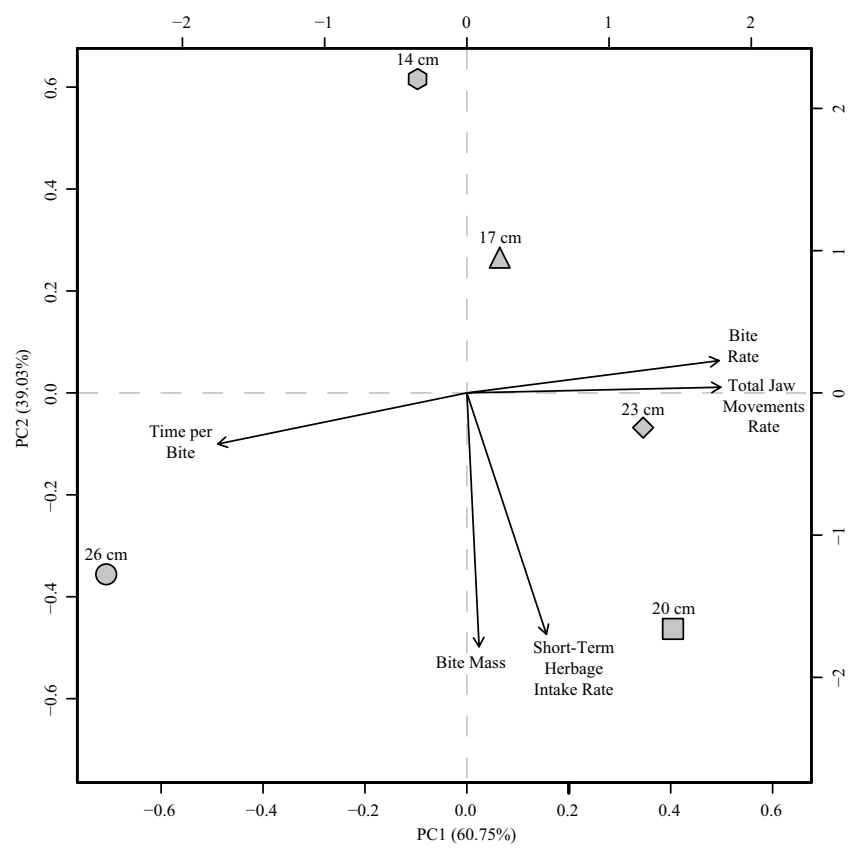

Figure 7. Principal component analysis of short-time herbage mass, bite mass, time per bite, bite rate and total jaw movements rate as a function of different Schedonorus arundinaceus [Schreb.] Dumort. (tall fescue) sward surface height (SSH). The two first dimensions explained $99.78 \%$ of the variability. The arrows within the graph represents distribution of variables and shows correlations between the different SSH and behaviour intake of sheep. The geometric shapes represent the mean values of SSH $(14,17,20,23$ and $26 \mathrm{~cm})$.

This is the same response reported by Amaral et al. ${ }^{17}$ and Fonseca et al. ${ }^{28}$. However, BM reached the maximum level at $22.8 \mathrm{~cm}$ and did not increase at higher SSH, even though bite depth was expected to increase linearly in response to $\mathrm{SSH}^{29}$. This curvilinear response in $\mathrm{BM}$ is considered classic in sheep studies ${ }^{14}$, which led us to consider the asymptotic part of the BM model and the reason for this behaviour.

Bite depth can be depressed when high tensile-resisting stems act as a barrier to bite formation, as reported by Benvenutti et al. ${ }^{37,38}$. However, the depth for a bite free of the horizon of the pseudo-stem + sheath (grazing horizon) was 9, 18, 27, 24, and $21 \mathrm{~cm}$ for the SSH of 14, 17, 20, 23 and $26 \mathrm{~cm}$, respectively (Figs. 1 and 2). Therefore, reduction of bite depth probably did not affect the response of BM and STIR to SSH. Barre ${ }^{18}$ found that shorter leaf lamina of perennial ryegrass was important in reducing the STIR of dairy cows. This may explain the 
lower STIR at SSH less than $22 \mathrm{~cm}$ in our study, as the length of the leaf lamina increased as the SSH increased (occupation by the leaf lamina of the upper strata of the sward at SSH above $20 \mathrm{~cm}$ ) (Fig. 4). Sward architecture affecting leaf distribution in the upper layers of taller swards would have played a role, in addition to bite area constraints. Pretorius et al. ${ }^{39}$ argued that geometric principles, for both plant and animal, can explain BM affecting STIR. Spatial distribution of forage resources is driven by the plant thinning law, where the number of plants per unit space decreases at a rate of $3 / 4$ power as plant mass increases. So, the dilution of plant parts in space as its mass increases would have consequences to herbivore foraging. Our LLM data in the upper layers of the sward suggest that the leaf content in the bite volume could explain BM saturation, resulting in the asymptotic model for STIR (Fig. 6).

Using realistic three-dimensional (3-D) modeling studies of perennial ryegrass and tall fescue swards, Verdenal et $a .^{40}$ and Sonohat et al. ${ }^{41}$ reported the increasing spatial distribution of the leaf blades in the upper strata of the sward with increasing SSH, resulting in a loss of verticality of leaf blades. As a consequence of this greater dispersion of leaf lamina, the animals are less likely to ingest large amounts of leaves in a single bite. Thus, the BM was likely reduced due to the lower accessibility of the leaf lamina mass, even though there was an increase in the leaf lamina bulk density in the higher SSH. Therefore, as the SSH approaches $23 \mathrm{~cm}$, the increase in leaf lamina mass in the upper strata did not reflect an increase in sheep bite mass, altering the relationship between the availability (plant) and the acquisition capacity (animal) of the preferred item (leaf lamina).

The increasing distance of the plant organs (divarication) is considered by Greenwood and Atkinson ${ }^{42}$, McQueen ${ }^{43}$ and Bond et al. ${ }^{44}$ as an ecological strategy of evolutionary defense of trees and shrubs against grazing, limiting the bite mass of animals. We are not aware of published reports that discuss the evidence of divarication in grass species within the same context. However, empirical observations suggest that this same process occurs between domestic herbivores and grasses. In the case of sheep, this phenomenon can be very important due to the morphology of the mouth and the style of feeding, i.e. small opening width of the mandible and use of the lips and teeth to perform the bite. According to Shipley ${ }^{8}$ the interaction between the morphology of the mouth and the structure of plants together determine the mass of the bite that an animal can obtain. Thus, bite mass and volume have a prominent role in intra- and interspecific interactions in herbivorous communities and in pasture landscapes. At the SSH of $26 \mathrm{~cm}$ there may have been a need for more interaction time of the animal with the sward in the formation of bites, such as the positioning of the head and the choice of the location of the bite (Fig. 7). This can be interpreted in Fig. 6c, where the bites with intermediate mass (between 60 and $100 \mathrm{mg}$ DM bite ${ }^{-1}$ ) and average TB greater than $1 \mathrm{~s}$ bite $^{-1}$ are for SSH of $26 \mathrm{~cm}$, compared with $0.96,0.95,0.94$ and $0.93 \mathrm{~s}$ bite $^{-1}$ for SSH of $14,17,20$ and $23 \mathrm{~cm}$, respectively.

According to Black and Kenney ${ }^{34}$, sheep tend to seek pasture structures that maximize the speed of ingestion. According to Baumont et al. ${ }^{30}$, the strategy of exploitation by the animals in horizons of the sward corresponds to a strategy of maximization of the quality of the diet and the STIR. Therefore, structures between SSH 20 and $23 \mathrm{~cm}$ would be within the best spatial distribution and amount of mass in the sward (Fig. 3), while the structures of SSH 14, 17 and $26 \mathrm{~cm}$ possibly promoted increasing displacement and search strategies by the animals, resulting in shorter time at feeding stations that lowered herbage intake, reflecting the theory of optimal foraging ${ }^{45,46}$. Different results regarding BR and TJMR as SSH increased were reported by Mezzalira et al. ${ }^{22}$ and Fonseca et al. ${ }^{28}$, who found increasing rates, which can be attributed mainly to the size of the animal, since those two studies were carried out with cattle. According to Illuis et al. ${ }^{47}$ animals of larger size are less constrained by the physical properties of the pasture structure. Black and Kenney ${ }^{34}$ did not observe changes in the rate of jaw movements of sheep in different structures of Pennisetum clandestinum Hochst. and perennial ryegrass. For the TB and SSH relationship, our results agree with those of Mezzalira et al. ${ }^{22}$ and Hirata et al. ${ }^{48}$.

The SSH of tall fescue corresponding to the maximum STIR of sheep was $22.3 \mathrm{~cm}$. That SSH can be adopted as an optimal pre-grazing height for rotational stocking systems. Carvalho ${ }^{29}$ suggested using the $\mathrm{SSH}$ corresponding to the maximum short-term intake rate as a target for pre-grazing height, with the post-grazing depletion criterion being a $40 \%$ decrease in $\mathrm{SSH}$ from the pre-grazing $\mathrm{SSH}^{22,28}$. He named this management strategy as "Rotatinuous stocking". Savian ${ }^{49}$, in a long-term experiment, compared "Rotatinuous stocking" with traditional rotational stocking of sheep grazing annual ryegrass pastures and found higher intake rate, higher daily intake, better chemical composition (crude protein, acid detergent fiber, and neutral detergent fiber), higher herbage digestibility and animal performance, and decreasing methane emissions under the "Rotatinuous stocking" management. Following the model of Carvalho ${ }^{22}$ and based on the optimal STIR for tall fescue found in this experiment, suggests a rotational stocking management system of placing animals on tall fescue swards when the pre-grazing SSH is $22.3 \mathrm{~cm}$ and removing animals when the $\mathrm{SSH}$ declines to $13.4 \mathrm{~cm}$.

\section{Materials and methods}

Ethics approval. The experimental animals were conducted in accordance with the Guide for the Care and Use of Agricultural Animals in Agricultural Research and Teaching and Directive 2010/63/EU of The European Parliament and of The Council of 22 September 2010 on the protection of animals used for scientific purposes. All procedures involving animals were approved by the Commission for Ethics in the Use of Animals of the Sector of Agricultural Sciences of the Federal University of Paraná (024/2016).

Experimental site. The experiment was carried out at the Canguiri experimental farm of the Federal University of Paraná-UFPR in Pinhais city, Paraná state, Brazil $\left(25^{\circ} 26^{\prime} 30^{\prime \prime} \mathrm{S}\right.$ and $\left.49^{\circ} 7^{\prime} 30^{\prime \prime} \mathrm{W}\right)$. The experiment was established in a $3,000 \mathrm{~m}^{2}$ experimental area of Schedonorus arundinaceus [Schreb.] Dumort cv. INIA Aurora (nomenclature suggested by Soreng et al. ${ }^{50}$, previously named Festuca arundinacea Schreb. and tall fescue as common name) sown in June 2015 using conventionally tilled seedbed preparation, with a seeding rate of $55 \mathrm{~kg} \mathrm{ha}^{-1}$. Beginning September 2015, the experimental area was managed under continuous stocking with 
sward surface height maintained between 10 and $15 \mathrm{~cm}$, except just prior to and during the grazing events when the different pre-grazing SSH treatments were imposed (see next section).

Nitrogen, phosphorus and potassium were applied uniformly to the experimental area. Before sowing, $540 \mathrm{~kg} \mathrm{ha}^{-1}$ of $\mathrm{P}_{2} \mathrm{O}_{5}$ was applied and after sowing (between 3 and 5 leaf stage) $200 \mathrm{~kg} \mathrm{ha}^{-1}$ of $\mathrm{N}$ and $60 \mathrm{~kg} \mathrm{ha}^{-1}$ of $\mathrm{K}_{2} \mathrm{O}$ were applied. In March 2016, $180 \mathrm{~kg} \mathrm{ha}^{-1}$ of $\mathrm{N}$ and $40 \mathrm{~kg} \mathrm{ha}^{-1}$ of $\mathrm{K}_{2} \mathrm{O}$ were applied. All fertilizer applications were based on the soil chemical analysis done before sowing (depth $0.00-0.20 \mathrm{~m}$ ). The soil test results were: $4.55 \%$ organic matter ([organic $\mathrm{C} \times 1.74] / 10), \mathrm{pH}=5.70\left(\mathrm{CaCl}_{2}\right)$, exchangeable aluminum $=0.00 \mathrm{cmol}_{\mathrm{c}} \mathrm{dm}^{-3}$, $\mathrm{K}=0.11 \mathrm{cmolc} \mathrm{dm}^{-3}, \mathrm{Ca}=5.00 \mathrm{cmol}_{\mathrm{c}} \mathrm{dm}^{-3}, \mathrm{Mg}=3.10 \mathrm{cmol}_{\mathrm{c}} \mathrm{dm}^{-3}, \mathrm{~V}(\%)=71$ and $\mathrm{P}=2.90 \mathrm{mg} \mathrm{dm}^{-3}$.

Treatments and experimental design. Five pre-grazing SSH (14, 17, 20, 23, $26 \mathrm{~cm})$ were evaluated in a randomized complete block design with four replicates. The heights were achieved by allowing regrowth and development of the plants from an initial residue height of $7 \mathrm{~cm}$. The time of day (morning or afternoon) was used as a blocking criterion. Twenty grazing tests of $45 \pm 1$ min were performed between 24 June and 12 July 2016, with two tests in the morning (between 8:30 and 9:30) and two in the afternoon (between 15:30 and 16:30).

Sward measurements. To determine the pre- and post-grazing SSH, a sward stick ${ }^{51}$ was used to for 150 point evaluations $\left(\approx 1\right.$ point. $\left.\mathrm{m}^{-2}\right)$ within each sampling unit. A total of three forage samples of $0.25 \mathrm{~m}^{2}$ each per experimental unit were harvested at ground level at pre- and post-grazing, to obtain the total herbage mass (HM), leaf lamina mass (LLM), pseudo-stem + sheath mass (PSM), senescent mass (SM) and other species mass (OSM), determined through morphological and botanical manual assessment.

The herbage mass was quantified in strata of the forage sward by collecting two samples from $0.02 \mathrm{~m}^{2}$ randomly distributed per experimental unit and stratifying them from the top of the plants to ground level in every vertical $0.03 \mathrm{~m}$ stratum. Those samples were separated into leaf lamina and pseudo-stem + sheath and subsequently the herbage bulk density was calculated by dividing the dry mass by the volume of the sampled cube in each stratum $\left(0.0006 \mathrm{~m}^{3}\right)$. The number of green leaves in each stratum was also recorded. All samples were dried in a forced air oven at $65^{\circ} \mathrm{C}$ until reaching constant weight for mass measurements.

Animal measurements. Six White Dorper $x$ Suffolk ewes were used with an average weight of $61.9 \pm 5.5 \mathrm{~kg}$ and two years of age. Three test animals were used to determine STIR. All animals were previously adapted to the experimental procedure and maintained in an area similar and adjacent to the experimental paddocks.

Before the grazing tests, the animals were equipped with diapers for collecting feces and urine and with IGER (Institute of Grassland and Environmental Research) Behaviour Recorders (Ultra Sound Advice, London, UK) ${ }^{52}$ which record grazing jaw movements and the effective eating time (the length of time that an animal spends eating during grazing). The data were analyzed with the Graze software ${ }^{53}$ and used to calculate bite mass (BM), bite rate (BR), time per bite (TB), total jaw movement rate (TJMR) and effective eating time (ET).

After the 45-min grazing test, the animals were allocated to an adjacent area of $9 \mathrm{~m}^{2}$ under open air condition, without access to water and food for $45 \mathrm{~min}$, to estimate insensitive weight losses $\left(\mathrm{H}_{2} \mathrm{O}\right.$ evaporation, $\mathrm{CO}_{2}$ and $\mathrm{CH}_{4}$ losses) $)^{54}$. The STIR was estimated by the double-weighing technique ${ }^{55}$. A digital balance (MGR-3000 Junior, Toledo, Canoas, Brazil) with a precision of $10 \mathrm{~g}$ was used to determine herbage intake. Equation (1) was used for the calculation of STIR:

$$
S T I R=d X\left\{\left[\frac{(W 2-W 1)}{(t 2-t 1)}\right]+\left[\frac{(W 3-W 4)}{(t 4-t 3)}\right]\right\} X\left[\frac{(t 2-t 1)}{E T}\right]
$$

where $d$ is the dry matter content of the herbage; $W 1$ and $W 2$ are pre- and post-grazing animal weight respectively; $t 1$ and $t 2$ are pre- and post-grazing time; $W 3$ and $W 4$ are animal weight pre- and post-insensible weight losses; $t 3$ and $t 4$ are pre- and post-insensible loss time and ET is effective eating time.

Bite mass was calculated by dividing the herbage intake during the grazing test by the total number of bites. Time per bite was calculated by dividing the total number of bites by ET. Total jaw movement rate was calculated by dividing the total number of jaw movements by the ET during the grazing test. The dry matter content of the herbage was accessed by samples collected by the continuous bite monitoring method ${ }^{56}$, after each grazing test. The fresh herbage mass was weighed after the grazing simulation and then dried in a forced air oven at $65^{\circ} \mathrm{C}$ until reaching constant weight.

Statistical analysis. The paddocks were considered as the experimental units and the animals as sampling units within each paddock. The data set were analyzed using the R software ${ }^{57}$. Data were submitted to analysis of variance (ANOVA). Bulk density data were analyzed with sources of variation being sward surface height, strata and their interaction. When the F-test for treatment differences was significant $(p<0.05)$, the treatment means were compared using the Tukey test, at a significance level of $5 \%$. The grazing variables (STIR, BM, BT, $\mathrm{TB}, \mathrm{TJMR}$ and ET) were analyzed using a quadratic model $\left(\mathrm{y}_{i j}=\mathrm{a}+\mathrm{bx}+\mathrm{cx}^{2}+\right.$ error $\left._{i j}\right)$. The model included SSH as a fixed effect and paddocks and animals within paddocks as random effects. The correlation coefficient (r) was used as a measure of dependence between the variables.

Received: 22 November 2019; Accepted: 1 July 2020

Published online: 16 July 2020 


\section{References}

1. Keating, B. A., Carberry, P., Thomas, S., Clark, J. Eco-efficient agriculture and climate change: Conceptual foundations and frameworks. In Eco-Efficiency: From Vision to Reality (ed. Hershey, C. H., Neate, P.) 19-28 (CIAT, Cali, 2013).

2. Herrero, M. et al. Livestock and the environment: What have we learned in the past decade?. Annu. Rev. Environ. Resour. 40, 177-202. https://doi.org/10.1146/annurev-environ-031113-093503 (2015).

3. Rouquette, F. M. Jr. Grazing systems research and impact of stocking strategies on pasture-animal production efficiencies. Crop Sci. 55, 2513-2530. https://doi.org/10.2135/cropsci2015.01.0062 (2015).

4. Carvalho, P. C. F. et al. From the bite to precision grazing: Understanding the plant-animal interface to exploit the multi-functionality of grasslands. R. Bras. Zootec. 38, 109-122 (2009).

5. Laca, E. A. Precision livestock production: Tools and concepts. R. Bras. Zootec. 38, 123-132 (2009).

6. Bonaudo, T. et al. Agroecological principles for the redesign of integrated crop-livestock systems. Eur. J. Agron. 57, 43-51. https ://doi.org/10.1016/j.eja.2013.09.010 (2014).

7. Massey, F. P. \& Hartley, S. E. Experimental demonstration of the anti-herbivore effects of silica in grasses: Impacts on foliage digestibility and vole growth rates. Proc. R. Soc. B. 273, 2299-2304. https://doi.org/10.1098/rspb.2006.3586 (2006).

8. Shipley, L. A. The influence of bite size on foraging at larger spatial and temporal scales by mammalian herbivores. Oikos 116, 1964-1974. https://doi.org/10.1111/j.2007.0030-1299.15974.x (2007).

9. Mendoza, M. \& Palmqvist, P. Hypsodonty in ungulates: An adaptation for grass consumption or for foraging in open habitat?. J. Zool. 274, 134-142. https://doi.org/10.1111/j.1469-7998.2007.00365.x (2008).

10. Strömberg, C. A. E. Evolution of grasses and grassland ecosystems. Ann. Rev. Earth Planet Sci. 39, 517-544. https://doi.org/10.1146/ annurev-earth-040809-152402 (2011).

11. Allden, W. G. \& Whittaker, I. A. M. D. The determinants of herbage intake by grazing sheep: The interrelationship of factors influencing herbage intake and availability. Aust. J. Agric. Res. 21, 755-766 (1970).

12. Laca, E. A., Ungar, E. D., Seligman, N. G. \& Demment, M. W. Effects of sward height and bulk density on the bite dimensions of cattle grazing homogeneous sward. Grass Forage Sci. 47, 91-102. https://doi.org/10.1111/j.1365-2494.1992.tb02251.x (1992).

13. Laca, E. A., Ortega, I. M. Integrating foraging mechanisms across spatial and temporal scales. In Proceedings of the 5th International Rangeland Congress (Scarnecchia, D.L., West, N.E., eds.) 129-132 (Society for Range Management, Denver, 1996).

14. Prache, S. \& Delagarde, R. The influence of vegetation characteristics on foraging strategy and ingestive behaviour. In Grassland Productivity and Ecosystem Services (eds Lemaire, G. et al.) 27-36 (CABI, Cambridge, 2011).

15. Gross, J. E., Shipley, L. A., Hobbs, N. T., Spalinger, D. E. \& Wunder, B. A. Functional response of herbivores in food-concentrated patches: Tests of a mechanistic model. Ecology 74, 778-791. https://doi.org/10.2307/1940805 (1993).

16. Decruyenaere, V., Buldgen, A. \& Stilmant, D. Factors affecting intake by grazing ruminants and related quantification methods: A review. Biotechnol. Agron. Soc. Environ. 13, 559-573 (2009).

17. Amaral, M. F. et al. Sward structure management for a maximum short-term intake rate in annual ryegrass. Grass Forage Sci. 68, 271-277. https://doi.org/10.1111/j.1365-2494.2012.00898.x (2012).

18. Barre, J. P. et al. Morphological characteristics of perennial ryegrass leaves that influence short-term intake in dairy cows. Agron. J. 98, 978-985. https://doi.org/10.2134/agronj2005.0213 (2006).

19. Hodgson J. Grazing Management: Science Into Practice. Longman Scientific and Technical. 1st edn. (Longman Group, London, 1990).

20. Fonseca, L. et al. Management targets for maximizing the short-term herbage intake rate of cattle grazing in Sorghum bicolor. Livest. Sci. 145, 205-211. https://doi.org/10.1016/j.livsci.2012.02.003 (2012).

21. Mezzalira, J. C. et al. Rotational grazing management in a tropical pasture to maximize the dairy cow's herbage intake rate. Arq. Bras. Med. Vet. Zootec. 65, 833-840 (2013).

22. Mezzalira, J. C. et al. Behavioural mechanisms of intake rate by heifers grazing swards of contrasting structures. Appl. Anim. Behav. Sci. 153, 1-9. https://doi.org/10.1016/j.applanim.2013.12.014 (2014).

23. Orr, R. et al. Intake characteristics of perennial ryegrass varieties when grazed by sheep under continuous stocking management. Euphytica 134, 247-260. https://doi.org/10.1023/B:EUPH.0000004949.49050.78 (2003).

24. Guzatti, G. C. et al. Changes in the short-term intake rate of herbage by heifers grazing annual grasses throughout the growing season. Grassl. Sci. 63, 255-264. https://doi.org/10.1111/grs.12170 (2017).

25. Bailey, D. W. et al. Mechanisms that result in large herbivore grazing distribution patterns. J. Range Manag. 49, 386-400 (1996).

26. Griffiths, W. M., Hodgson, J. \& Arnold, G. C. The influence of sward canopy structure on foraging decisions by grazing cattle I. Patch selection. Grass Forage Sci. 58, 112-124. https://doi.org/10.1046/j.1365-2494.2003.00360.x (2003).

27. Gonçalves, E. N. et al. Plant-animal relationships in pastoral heterogeneous environment: Process of herbage intake. R. Bras. Zootec. 38, 611-617 (2009).

28. Fonseca, L. et al. Effect of sward surface height and level of herbage depletion on bite features of cattle grazing Sorghum bicolor swards. J. Anim. Sci. 91, 4357-4365. https://doi.org/10.2527/jas2012-5602 (2013).

29. Carvalho, P. C. F. Harry stobbs memorial lecture: Can grazing behavior support innovations in grassland management?. Trop. Grassl-Forrajes Trop. 1, 137-155 (2013).

30. Baumont, R., Cohen-Salmon, D., Prache, S. \& Sauvant, D. A mechanistic model of intake and grazing behaviour in sheep integrating sward architecture and animal decisions. Anim. Feed Sci. Technol. 112, 5-28. https://doi.org/10.1016/j.anifeedsci.2003.10.005 (2004).

31. Mezzalira, J. C. et al. Mechanisms and implications of a type iv functional response for short-term intake rate of dry matter in large mammalian herbivores. J. Anim. Ecol. 86, 1159-1168. https://doi.org/10.1111/1365-2656.12698 (2017).

32. Ungar, E. D., Genizi, A. \& Demment, M. W. Bite dimensions and herbage intake by cattle grazing short hand-constructed swards. Agron. J. 83, 973-978. https://doi.org/10.2134/agronj1991.00021962008300060010x (1991).

33. Laca, E. A., Ungar, E. D. \& Demment, M. W. Mechanisms of handling time and intake rate of a large mammalian grazer. Appl. Anim. Behav. Sci. 39, 3-19. https://doi.org/10.1016/0168-1591(94)90011-6 (1994).

34. Black, J. L. \& Kenney, P. A. Factors affecting diet selection by sheep. II. Height and density of pasture. Aust. J. Agric. Res. 35, 551-563. https://doi.org/10.1071/AR9840565 (1984).

35. Burlison, A. J., Hodgson, J. \& Illius, A. W. Sward canopy structure and the bite dimensions and bite weight of grazing sheep. Grass Forage Sci. 46, 29-38. https://doi.org/10.1111/j.1365-2494.1991.tb02205.x (1991).

36. Gregorini, P. et al. Effect of herbage depletion on short-term foraging dynamics and diet quality of steers grazing wheat pastures. J. Anim. Sci. 89, 3824-3830. https://doi.org/10.2527/jas.2010-3725 (2011).

37. Benvenutti, M. A., Gordon, I. J. \& Poppi, D. P. The effect of the density and physical properties of grass stems on the foraging behaviour and instantaneous intake rate by cattle grazing an artificial reproductive tropical sward. Grass Forage Sci. 61, 272-281. https://doi.org/10.1111/j.1365-2494.2006.00531.x (2006).

38. Benvenutti, M. A., Gordon, I. J. \& Poppi, D. P. The effects of stem density of tropical swards and age of grazing cattle on their foraging behaviour. Grass Forage Sci. 63, 1-8. https://doi.org/10.1111/j.1365-2494.2007.00609.x (2008).

39. Pretorius, Y. et al. Why elephant have trunks and giraffe long tongues: how plants shape large herbivoremouth morphology. Acta Zool. 97, 246-254. https://doi.org/10.1111/azo.12121 (2016). 
40. Verdenal, A., Combes, D. \& Escobar-Gutiérrez, A. J. A study of ryegrass architecture as a self-regulated system, using functionalstructural plant modelling. Funct. Plant Biol. 35, 911-924. https://doi.org/10.1071/FP08050 (2008).

41. Sonohat, G. et al. Leaf dispersion and light partitioning in three dimensionally digitized tall fescue-white clover mixtures. Plant Cell Environ. 25, 529-538. https://doi.org/10.1046/j.1365-3040.2002.00833.x (2002).

42. Greenwood, R. M. \& Atkinson, I. A. E. Evolution of divaricating plants in new zealand in relation to moa browsing. Proc. N. Z. Ecol. Soc. 24, 21-33 (1977).

43. McQueen, D. R. Divaricating shrubs in patagonia and new zealand. N Z J. Ecol. 24, 69-80 (2000).

44. Bond, W. J., Lee, W. G. \& Craine, J. M. Plant structural defenses against browsing birds: A legacy of New Zealand' extinct moas. Oikos 104, 500-508. https://doi.org/10.1111/j.0030-1299.2004.12720.x (2004).

45. Schoener, T. W. Theory of feeding strategies. Annu. Rev. Ecol. Evol. Syst. 2, 369-404 (1971).

46. Pyke, G. H., Pulliam, H. R. \& Charnov, E. L. Optimal foraging: A selective review of theory and tests. Q. Rev. Biol. 52, 137-154 (1977).

47. Illius, A. W., Gordon, I. J., Milne, J. D. \& Wright, W. Costs and benefits of foraging on grasses varying in canopy structure and resistance to defoliation. Funct. Ecol. 9, 894-903. https://doi.org/10.2307/2389988 (1995).

48. Hirata, M., Kunieda, E. \& Tobisa, M. Short-term ingestive behaviour of cattle grazing tropical stoloniferous grasses with contrasting growth forms. J. Agric. Sci. 148, 615-624. https://doi.org/10.1017/S0021859610000353 (2010).

49. Savian, J. V. et al. Rotatinuous stocking: A grazing management innovation that has high potential to mitigate methane emissions by sheep. J. Clean Prod. 186, 602-608. https://doi.org/10.1016/j.jclepro.2018.03.162 (2018).

50. Soreng, R. J., Terrell, E. E., Wiersema, J., Darbyshire, S. J. (1488) Proposal to conserve the name Schedonorus arundinaceus (Schreb.) Dumort. against Schedonorus arundinaceus Roem. \& Schult. (Poaceae: Poeae). Taxonomy 50, 915-917 (2001).

51. Barthram GT. Experimental techniques: The HFRO sward stick. In Biennial Report of the Hill Farming Research Organization (ed. Alcock, M. M.) 29-30 (Midlothian: Hill Farming Research Organization, 1985).

52. Rutter, S. M., Champion, R. A. \& Penning, P. D. An automatic system to record foraging behaviour in free-ranging ruminants. Appl. Anim. Behav. Sci. 54, 185-195. https://doi.org/10.1016/S0168-1591(96)01191-4 (1997).

53. Rutter, S. M. Graze: A program to analyze recordings of the jaw movements of ruminants. Behav. Res. Methods 32, 86-92. https:// doi.org/10.3758/BF03200791 (2000).

54. Gibb M. Animal grazing/intake terminology and definitions. In Pasture Ecology and Animal Intake 21-37 (Proceedings 3, Dublin, 1998).

55. Penning, P. D. \& Hooper, G. E. N. An evaluation of the use of short-term weight changes in grazing sheep for estimating herbage intake. Grass Forage Sci. 40, 79-84. https://doi.org/10.1111/j.1365-2494.1985.tb01722.x (1985).

56. Bonnet, O. J. F. et al. Continuous bite monitoring: A method to assess the foraging dynamics of herbivores in natural grazing conditions. Anim. Prod. Sci. 55, 339-349. https://doi.org/10.1071/AN14540 (2015).

57. R Development Core Team. R: A Language and Environment for Statistical Computing (R Foundation for Statistical Computing, Vienna, 2016).

\title{
Acknowledgements
}

We thank to employees of the Department of Crop Production and Protection (UFPR), to employees of Canguiri experimental farm (UFPR) and to undergraduate student of Technological Center of Innovation in Agriculture (UFPR) for the contributions in the development and conduct of field experiment. This work was supported by postgraduate scholarship of Coordination for the Improvement of Higher Education Personnel (CAPES) of the Brazilian Ministry of Education. We also thank the National Council for Scientific and Technological Development $(\mathrm{CNPq})$ for the research grant.

\section{Author contributions}

L.S.S. designed the study, performed all experiments, analyzed the data and wrote the manuscript, A.M. conceived the idea for the study with R.M.S. and designed the study and revised manuscript, R.M.S. conceived the idea of the study with A.M. and revised the manuscript, C.R.L. revised the manuscript, A.L.G.M. supplied the experimental animals and revised manuscript, R.F.M. and D.F.F.S. helped on samples collection and analysis, C.B. analyzed the data and revised manuscript and P.C.F.C. advised in the design and conduct of the study, supplied experimental equipment and revised manuscript. All authors read and approved the final manuscript.

\section{Competing interests}

The authors declare no competing interests.

\section{Additional information}

Correspondence and requests for materials should be addressed to L.S.S.

Reprints and permissions information is available at www.nature.com/reprints.

Publisher's note Springer Nature remains neutral with regard to jurisdictional claims in published maps and institutional affiliations.

\begin{abstract}
Open Access This article is licensed under a Creative Commons Attribution 4.0 International License, which permits use, sharing, adaptation, distribution and reproduction in any medium or format, as long as you give appropriate credit to the original author(s) and the source, provide a link to the Creative Commons license, and indicate if changes were made. The images or other third party material in this article are included in the article's Creative Commons license, unless indicated otherwise in a credit line to the material. If material is not included in the article's Creative Commons license and your intended use is not permitted by statutory regulation or exceeds the permitted use, you will need to obtain permission directly from the copyright holder. To view a copy of this license, visit http://creativecommons.org/licenses/by/4.0/.
\end{abstract}

(c) The Author(s) 2020 